\title{
PERSONAL INCOME TAX REFORM IN LATVIA: ASSESSMENT OF EFFECT
}

\author{
Larisa BULE ${ }^{1 *}$, Līga LEITĀNE ${ }^{2}$, Kristīne ROZĪTE ${ }^{3}$ \\ ${ }^{1,2}$ Department of Finance and Accounting, Faculty of Business, Management and Economics, \\ University of Latvia, Aspazijas boulevard 5, LV-1050, Rīga, Latvia \\ ${ }^{3}$ Department of Economics, Faculty of Business, Management and Economics, \\ University of Latvia, Aspazijas boulevard 5, LV-1050, Rīga, Latvia \\ *E-mail: larisa.bule@lu.lv
}

\begin{abstract}
Personal income tax (PIT) policy in Latvia has been changed significantly in 2018 with the aim to reduce the tax burden and increase the income of working population by amending progressive tax rates and increasing the nontaxable minimum and minimum wage.

Purpose - the aim of this study is to estimate the impact of PIT reform by assessing the effect of implementation of non-taxable minimum, deductions and substantiated spending on the dynamics of income and tax administration efficiency.

Research methodology - PIT theoretic and normative concepts have been analyzed; unpublished data on actual wages in 2015-2018 provided by Latvian State Revenue Service and State Social Insurance Agency have been estimated.

Findings - the main conclusion of this study is that the aim of the reform has not been achieved: income inequality hasn't been reduced, an increase of income has been irrelevant, the gains from the reform have become unobtainable for the most unprotected groups because of the insufficient level of income. The implementation of the differentiated non-taxable minimum has generated PIT debts and higher administrative burden.
\end{abstract}

Practical implications - the study may be implemented in case of progressive PIT for the reassessment of the tax framework and its future development.

Originality/Value - this study is original, the actual effect of PIT reform in Latvia previously hasn't been analyzed.

Keywords: personal income tax, progressivity, reform, tax policy.

JEL Classification: H24, I31.

Conference topic: Legal Business Environment.

\section{Introduction}

Personal income tax (PIT) is one the oldest economic categories, it always served as an important source of financing for government's activities. However, it is necessary to ensure the condition that besides the provision of sufficient public revenue, PIT is also implemented in the reduction of income inequality and promotion of social fairness. It has been said that "what the government gives it must first take away" (James \& Nobes, 2010/2011). Nowadays PIT still is an instrument of "taking away", but at the same time, it is a powerful method of impact on welfare, demand labor supply and many other areas of economic activities.

The economic significance of tax deductions, allowances and credit can be estimated via a set of criteria. The first group of criteria includes different aspects of microeconomic efficiency; the second one- the ability of a government to achieve its strategic goals by implementing available instruments, that are not always tax deductions; the third group is associated with the effective application of fiscal policy, that should be based on the principles of simplicity, stability transparency, and responsibility. Therefore, the analysis of tax deductions, allowances and credit should be performed in the context of the previously mentioned groups of criteria.

Personal income tax is one of the labor taxes, which formerly affected only a narrow group of individuals and its rates were low. BetweenWorld War 1and, most of the developed countries started to apply PIT more extensively. The initial concepts of PIT divided income taxation into global income taxation and schedule income taxation. AfterWorld War 2 governments continued to finance the growth and expansion of activities by extending income taxation and introducing its progressivity. However, at the end of the 20th century, the majority of economists supposed, that high

(C) 2019 Authors. Published by VGTU Press. This is an open-access article distributed under the terms of the Creative Commons Attribution (http://creativecommons.org/licenses/by/4.0/) License, which permits unrestricted use, distribution, and reproduction in any medium, provided the original author and source are credited. 
tax rates worsen economic activities, as well as have a negative effect on income redistribution and level of welfare (Bird \& Zolt, The limited role of the personal income tax in developing countries, 2005).

At present personal income taxation is a complex and multilateral economic term. PIT development depends on the economic environment and the aims of public economic policy. Almost everywhere PIT is significant or in some countries, the most important source of public revenue and its relevance depends on the level of development of a national economy. PIT has an impact on consumption and can encourage, limit or decrease it. Therefore, the main problem of income taxation is how to obtain an optimal balance between social fairness and economic efficiency of tax. In other words, it is necessary to work out the combination of PIT elements that ensures maximal equity in income distribution, minimizes social differentiation and has the lowest possible negative impact on tax payer's interest.

From the point of view of the first group of criteria the implementation of tax deductions and other rights to decrease the number of tax payments can lead to a considerable microeconomic disproportions and preferences, but the second group of criteria provides an opportunity to assess the impact of tax cuts on social inequality, as well as on the option to apply alternative measures, which are beyond the framework of tax policy (European Commission, 2014). The estimation from the viewpoint of the third group of criteria provides an understanding of the effect of tax decrease on fiscal aspects. It is recommended to apply tax reducing factors with caution, as far as they can make the tax system more complex and unstable, increase tax administration costs and cause welfares decline. However, in comparison with the government's direct goals, the above-mentioned factors are usually hardly controlled by a government, are very unstable and depend on the lobby's influence.

\section{Main approaches to personal income tax progressivity assessment}

First studies dedicated to the assessment of progressivity appeared already in the 20th century: in 1948 R.Musgrave and T.Thin proposed 4 parameters for particular tax progressivity estimation and 1 parameter for evaluating the progressivity of a tax system (Musgrave \& Thin, 1948). In the 70's N. C. Kakwani, D. Suits and other authors (Reynolds, Smolensky, Piketty, Saez, Jakobsson, Formby) specified and expanded the previous studies (Kakwani, 1977; Suits, 1977), the Suits index was introduced. It became a tax-based analog of the Gini coefficient and was constructed from an income concentration curve- a graph of cumulative tax burden against cumulative income (Slemrod, 1996).

Different approaches to the assessment of the tax system were considered. Musgrave and Thin (1948) proposed two models of estimating the progressivity of tax liabilities according to the scope of income shift. If income shift is not significant, the liability progression (LP) may be calculated in the following way:

$$
L P=\frac{\Delta t(y)}{\Delta y} \times \frac{y}{t(y)} \text { or } L P=\frac{m(y)}{a(y)},
$$

where: $y$ - income; $\Delta y$-income changes; $a(y)$ - average tax rate; $\Delta a(y)$ - average tax rate changes; $m(y)$ - marginal tax rate; $t(y)$ - tax liability; $\Delta t(y)$ - tax liability changes.

If income changes are significant, the formula is as follows:

$$
L P=\frac{\Delta t(y)}{t(y)-\Delta t(y)} \times \frac{y-\Delta y}{\Delta y} \quad \text { or } \quad L P=\frac{\Delta m(y)}{a(y)},
$$

where: $\Delta m(y)$ - changes in marginal tax rate.

If the coefficient equals 1 , then tax is proportional, if it exceeds 1 , then tax is progressive and if it is lower than 1 , the tax is regressive. This ratio shows how many times taxation has increased as income has increased at a given level (Govori, 2015).

Musgrave and Thin (1948) also proposed the coefficient of residual income progression (RP), which measures the ratio of the percentage change in income after tax, to the percentage change in income before tax. In case of insignificant income changes the coefficient is calculated in the following way:

$$
R P=\frac{\Delta(y-t(y))}{\Delta y} \times \frac{y}{y-t(y)} \quad \text { or } \quad R p=\frac{1-m(y)}{1-a(y)} .
$$

If there are major changes in income, the coefficient is calculated as:

$$
R P=\frac{\Delta(y-t(y))}{(y-\Delta y)-(t-\Delta t)} \times \frac{y-\Delta y}{\Delta y} .
$$

If the coefficient equals 1 , taxation is proportional, it exceeds 1 , taxation is regressive, and if it falls short of 1 , then taxation is progressive. 
In 1960 A. Pigou suggested the formula of average rate progression $(A P)$. It measures the change rate of the average tax rate (Pigou, 1960).

$$
A P=\frac{\Delta a(y)}{\Delta y} \quad \text { or } \quad A P=\frac{m(y)-a(y)}{y-\Delta y}
$$

If $A P=0$ tax structure is proportional, $A P<0$ tax structure is regressive, $A P>0$ - progressive.

Pigou (1960) also determined the coefficient of marginal rate progression $(M P)$, which is defined as the ratio of change in the marginal tax rate to the change in income:

$$
M P=\frac{\Delta m(y)}{\Delta y} .
$$

If the coefficient is equal to zero, the tax is proportional, if exceeds zero, the tax is progressive and if falls short of zero, the tax is regressive.

All models mentioned above take into account the income change or average tax rate in the denominator. However, the results obtained by measuring the rate of progression in a given level of income from these methods do not show any connection with the previous income level. Therefore, the coefficients of Musgrave, Thin and Pigou remain fundamental for further theoretic research and model development.

\section{Research methodology}

Basic assessment of PIT reform in Latvia has been developed according to the fundamental principles of progressivity's measuring as in Musgarve and Thin (1948) and Pigou (1960). Further estimation of the reform's impact has been based on the criteria groups formulated by the EU common statements (European Commission, 2015). For more precise analysis an actual income data of all taxpayers (from 785863 persons in January 2015 to 820455 persons in June 2018) provided by State Revenue Service (SRS) and State Social Insurance Agency (SSIA) have been estimated and a forecast of income dynamics has been carried out. Economic consequences of the normative framework in the context of different levels of income have been assessed. The tax burden has been calculated as follows: the total amount of employee's social insurance contributions and personal income tax has been divided by gross earnings. The tax burden on median gross earnings has been calculated as well. Median earnings have been used due to the significant difference between the average earnings and its median indicator. The approaches of economic and statistical analysis have been applied. Salaries and wages have been considered as earnings, i.e. average earnings characterize the amount of labor income including salaries and wages.

\section{Assessment of PIT normative framework in the context of legal principles}

Governments have a wide freedom of action in the development and implementation of tax policies. The freedom of action includes the rights to decide what tax rates to impose and on what categories of persons. A decision of a policymaker on the need for a particular tax and its relevance is a question of politics and feasibility (Constitutional Court of the Republic of Latvia, 2007). The tax duty stated by a government doesn't affect a person's basic rights; therefore, the scope of constitutional control regarding the process of tax calculation is relatively narrow. However, the specificity of the area of tax law determines also the scope of constitutional supervision. From the viewpoint of the restriction of rights, Constitutional Court may consider if tax payment or tax burden is irrelevant in the case of the particular taxpayer and if tax legislation complies with the universal fundamental rights. Tax standards must be justified by reasonable and intelligent assumptions (Constitutional Court of the Republic of Latvia, 2010). This statement arises from the basic norms and from the principle of a socially responsible democratic country, which is claimed in the Constitution of the Republic of Latvia. Moreover, while realizing the freedom of action in the field of tax policy, policymakers must follow the principles of efficiency, fairness, solidarity, and promptness (Constitutional Court of the Republic of Latvia, 2017). The same freedom of action is provided to a government in the development and implementation of of-of social policy. An ability of a government to establish an efficient and working system of social security depends on the available financing and general economic situation (Constitutional Court of the Republic of Latvia, 2006). However, the freedom of action is not unlimited; the government must operate vigorously in building: 1) efficient; 2) fair and 3) sustainable system of social security (Kovalevska, 2011). Taking into consideration that government's freedom of action is limited with Constitutional and legal framework, hereinafter the relevance of current PIT deductions to Constitutional principles is going to be analyzed. But first of all the main legal principle related to tax law, including tax deductions, should be specified, as well as judicature's conclusions on the implementation of principles. Fairness is the main objective of positive rights and also the foundation for their existence. Fairness determines the importance of implementing the principles of universal rights that are consequently applied unconstitutional supervision when assessing the legitimacy of legal norms (Pētersons, 2001). This conclusion may be fully referred $t$ as the specific principles of tax law. The principle of fairness in economics is usually related to the 
principle of equality, this combination is supposed to be one of the main of the universal rights, it provides an equal treatment for all taxpayers despite the area of economy, form of business, quantity, region and other factors (Andrejeva $\&$ Ketners, 2007). With the aim to achieve fairness the following conditions must be assured: 1) balance and consensus, 2) equality of the individuals in the equal and comparable position and 3) distribution of welfare according to a credit. The fairness is provided only when the government's action in addressing particular problems conforms to these criteria (Satversmes tiesa, 2016). Socially responsible is a country that attempts to achieve the widest scope of fairness in legislation, public management and judicature. The objective of the socially responsible country is to equalize significant social disparities and to provide appropriate living standard (Konstitucionālo tiesību komisija, 2012). In the context of tax law, it is necessary to comply with two principles, which arise from the primary principle of a socially responsible country. One of them is the principle of social fairness. It is concerned with the equalization of social discrepancies and means the redistribution of material and immaterial welfare from the richest individuals to the poorest one, as far as the government supports the weakest and limits the strongest. This restricting policy is in the competence of the state; however, it is not allowed to redistribute welfare from the poorest to the richest (Balodis, 2014). The second important principle of the socially responsible country is the responsibility of an individual or mutual reciprocity. The introduction to the Constitution of the Republic of Latvia claims that everyone is obliged to take care of himself/herself, his/her relatives and society in general. It means that not unilateral but mutual solidarity exists between any individual and state (Balodis, 2014). The scope of concern proportionally depends on the individual's resources; the more resources a person has the more care must be provided to the others. This statement mostly relates to the resources different from energy and time since energy and time are distributed almost equally. Consequently, the wealthier and more capable individual has a higher responsibility to take care than poorer and less capable: who can more, must give more. This statement justifies, for example, a progressive tax rate (Šulmane, 2013). Amongst the principles of universal rights principle of efficiency is relatively new. The term "efficiency" means something providing the required results something that has an effect. Efficiency is a feature of quality, its criteria may be determined according to the essence of a particular case. The dimension of economic efficiency in a democratic country is a clarifying element of fairness covered by the requirement of consensus and balance, equality and proportional distribution of welfare. The constitutional court is competent to consider if the justification of fairness principle, based on the assumptions of economic efficiency and carried out by policymakers, complies with the fundamental norm- democratic legal state (Satversmes tiesa, 2016).

Assessment of a normative regulation of non-taxable minimum demonstrates that the latter is apart of the labor tax reform performed in the framework of tax reform. The order No245issued by the Cabinet of Ministers of Latvia in 2017 stated objective of the labor tax reform as the reduction of PIT burden and income growth maintained by lowering PIT rate, increasing the non-taxable minimum and minimum wage (Cabinet of Ministers, 2017c). The idea of increasing the non-taxable minimum wasn't new, but in comparison with previous documents the order No245 justified the motivation of that action as an importance of increasing the differentiated non-taxable minimum and its full implementation in the current period, but not after the submission of an annual income report (Cabinet of Ministers, 2017a). The legislation in force also claims that the goal of the non-taxable minimum is to provide its implementation already in a current taxation period; thus not to undertake huge refunding after the submission of annual income report. From the point of view of a policymaker, this solution is extremely important to low-income taxpayers (The Government of the Republic of Latvia, 2017). Estimating the prospects of inequality reduction it is possible to appreciate the fact that the government has determined the more progressive policy of non-taxable minimum simultaneously retaining the previous statements. By adopting the differentiated non-taxable minimum the principles of sustainability, social fairness and solidarity have been promoted.

According to the measuring approach of Musgrave and Thin (Musgrave \& Thin, 1948) Latvian PIT system is progressive, even double progressive. However, even low-income taxpayers have got wider financial support, the way this support is provided may become unfair and inefficient due to the following statements.

First of all, there is a conflict between the way of support and the ideology of non-taxable minimum, namely, the delivery of financing necessary for basic existence. Income refunding in the following year or later couldn't be considered as fair and relevant.

Second, the system, that provides refunding later, practices borrowing from taxpayers, but since interest is not paid the system disrupts the principle of tax neutrality and hence the broader principle of fairness.

Third, since taxpayers may implement the differentiated non-taxable minimum only in a year and receive refunding in one and a half year the measures of inequality reduction are postponed, thus not prompt.

\section{Empirical evidence}

The effect of PIT reform may be estimated in the context of different indicators. The main changes are characterized by the dynamics of the tax burden, changes in net income and taxpayer's opportunity to implement the non-taxable minimum, tax deduction, and substantiated expenditures. Table 1 shows the ratio of deducted taxes (PIT and employee's social insurance contributions) to the average gross income of a specific group. 
The tax burden of individuals without dependants has been increasing in 2015-2017 but in 2018 it has shifted down to the level of 2015. The same trends have been observed in the case of 1 and 2 dependants. In the case of 3 dependants, the tax burden has been growing steadily, but if the amount of dependants has been 4 to 6 the tax burden hasn't changed in 2015-2017 and increased in 2018.

Table 1. The ratio of deducted taxes (PIT and employee's social insurance contributions) to the average gross earnings in 2015-2018, \% (source: authors' estimation based on the unpublished data of SRS and SSIA)

\begin{tabular}{|c|c|c|c|c|c|c|c|}
\hline Year & no dependants & 1 dependant & 2 dependants & 3 dependants & 4 dependants & 5 dependants & 6 dependants \\
\hline 2015. & 28.75 & 23.62 & 18.5 & 13.37 & 10.5 & 10.5 & 10.5 \\
\hline 2016. & 28.9 & 23.81 & 18.71 & 13.61 & 10.5 & 10.5 & 10.5 \\
\hline 2017. & 29.46 & 24.72 & 19.99 & 15.25 & 10.5 & 10.5 & 10.5 \\
\hline 2018. & 28.8 & 24.36 & 19.91 & 15.46 & 11.02 & 11 & 11 \\
\hline
\end{tabular}

An indicator of average gross earnings also includes extremely high and extremely low salaries and wages, therefore the authors'opinion, the median indicator provides a more precise illustration. Figure 1 shows the trends of the average and median gross earnings and substantial differences between the indicators.

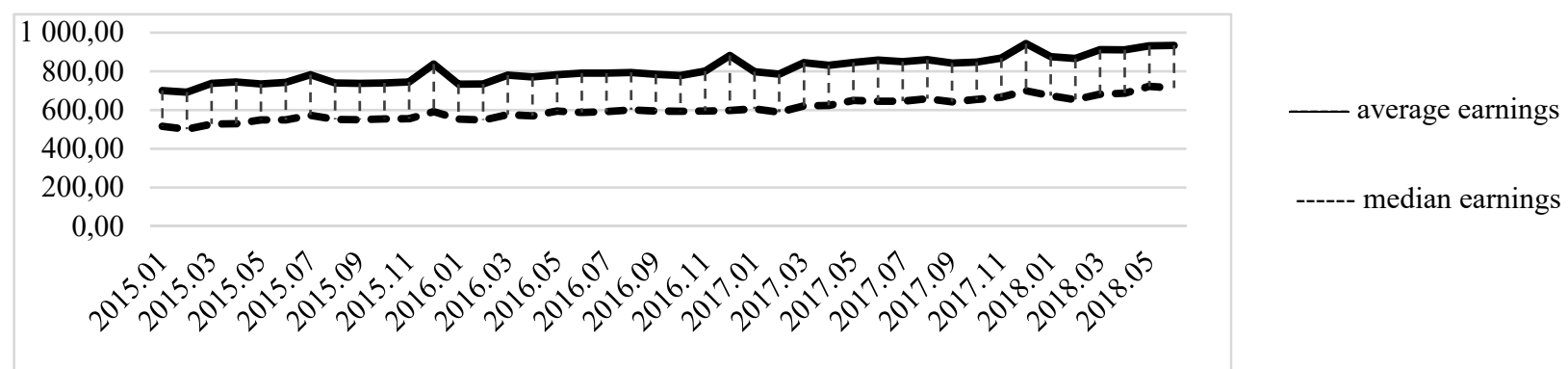

Figure 1. Dynamics of average and median monthly earnings in 2015-2018, EUR (source: Central Statistical Bureau of Latvia, 2018)

Median income is up to $32 \%$ lower than average income. For example, in June 2018 the difference is 221 euro or $24 \%$. This distinction may be considered as rather significant; in general, the assessment of average earnings is highly influenced by few extremely high salaries and wages, meanwhile, half of all taxpayers earn less than median income The only positive trend here is that the distinction tends to decrease.

The tax burden on the median earnings has been growing during the whole period, furthermore, the most significant increase has been observed in case of 2 and 3 dependants- the dynamics illustrated in Table 2 that might be commented only adversely.

Table 2. The ratio of deducted taxes (PIT and employee's social insurance contributions) to the median gross earnings in 2015-2018, \% (source: authors' estimation based on the unpublished data of SRS and SSIA)

\begin{tabular}{|c|c|c|c|c|c|c|c|}
\hline Year & $\begin{array}{c}\text { no } \\
\text { dependants }\end{array}$ & 1 dependant & 2 dependants & 3 dependants & 4 dependants & 5 dependants & 6 dependants \\
\hline 2015. & 27.64 & 20.04 & 12.45 & 10.5 & 10.5 & 10.5 & 10.5 \\
\hline 2016. & 27.95 & 20.63 & 13.31 & 10.5 & 10.5 & 10.5 & 10.5 \\
\hline 2017. & 28.79 & 22.08 & 15.37 & 10.5 & 10.5 & 10.5 & 10.5 \\
\hline 2018. & 28.8 & 23.09 & 17.37 & 11.65 & 11 & 11 & 11 \\
\hline
\end{tabular}

An establishment of a non-taxable minimum as an exception from a general tax commitment is based on the value of respecting human's pride, that is the duty of democratic state (The Parliament of the Republic of Latvia, 1922). The essence of the non-taxable minimum is the provision of income necessary for an individual's existence. It means, that the income that provides a minimum level of existence must be excluded from the PIT taxable basis (Andrejeva \& Ketners, 2007). The non-taxable minimum may be also defined as a basic allowance of the PIT system that is equal to anyone and ensures the subsistence minimum (Ketners, 2013). In 2018the formula of the annual differentiated nontaxable minimum in Latvia is the following (Cabinet of Ministers, 2017b):

$$
A D N M=A N M_{\max }-C \times\left(A I-A I_{\min }\right),
$$

where: $A D N M$ - annual differentiated non-taxable minimum; $A N M_{\max }$ - maximum annual non-taxable minimum; $A I-$ annual earnings of the particular taxpayer; $C$-coefficient, calculated as follows: 


$$
C=\frac{A N M_{\max }}{\left(A I_{\max }-A I_{\min }\right)}
$$

where: $A I_{\min }$ - government's stated amount of annual income when the maximum non-taxable minimum is applied $A I_{\max }$ - government's stated amount of annual income when the non-taxable minimum is not applied.

Table 3 illustrates the dynamics of mentioned indicators specified by the Latvian government for the period of 2018-2020.

Table 3. Dynamics of indicators used in the differentiated non-taxable minimum calculation in 2018-2020 (source: Cabinet of Ministers, 2017b)

\begin{tabular}{|l|c|c|c|}
\hline \multicolumn{1}{|c|}{ Indicator } & 2018 & 2019 & 2020 \\
\hline $\begin{array}{l}\text { Maximum annual non-taxable minimum, } \\
\text { EUR }\end{array}$ & 2400 & 2760 & 3000 \\
\hline $\begin{array}{l}\text { Annual income, when the non-taxable } \\
\text { minimum is not applied, EUR }\end{array}$ & 12000 & 13200 & 14400 \\
\hline $\begin{array}{l}\text { Annual income when the maximum } \\
\text { non-taxable minimum is applied }\end{array}$ & 5280 & 5280 & 5280 \\
\hline Coefficient & 0.35714 & 0.34848 & 0.32895 \\
\hline
\end{tabular}

It is necessary to mention that the individual non-taxable minimum is estimated in July, but from January to July the projected monthly differentiated non-taxable minimum is applied. The projection is based on historical data, i.e. particular taxpayer's income of the previous year and is assessed as follows:

$$
P M N M=\frac{A N M_{\max }-C \times\left(A I_{\operatorname{mavg} \times 12}-A I_{\min }\right)}{12},
$$

where: $P M N M$ - projected monthly non-taxable minimum; $A I_{\text {mavg }}$ - the average size of taxpayer's monthly income.

It should be emphasized that all indicators except $A I_{\text {mavg }}$ are of a current year, but $A I_{\text {mavg }}$ is the historic indicator of a previous year. $P M N M$ and $A D N M$ are estimated by the State Revenue Service but anyway, the procedures of calculation obviously look to be too complex to an average taxpayer.

Since 2018 the formula of the differentiated non-taxable minimum remains very similar to the previous one, however in 2016-2017, when calculating the coefficient, the minimum non-taxable minimum (equal, constant and implemented to everyone) has been taken into consideration. In 2018 the minimum of the minimum is not taken into account anymore, hence the differentiated non-taxable minimum is determined purely individually. This difference creates a significant impact on the consequences of non-taxable minimum's application to a specific taxpayer and becomes an aspect of inequality. Monthly differentiated non-taxable minimums itself might be calculated correctly, but the calculation is built on historical data that is not equal to person's future earnings, therefore, the annual differentiated minimum is estimated and implemented only when an annual income report is submitted. Due to the potential differences in the calculation of monthly and annual indicators PIT debt or overpayment could emerge. At the beginning of 201, the State Revenue Service has published the information about 60000 debtors (about $8 \%$ of taxpayers) (State Revenue Service, 2019). As Table 4 shows, the extent of debt and overpayment is rather wide.

Table 4. Assessment of PIT debt or repayment extent in 2018-2020, EUR (source: authors' estimation based on SRS and SSIA data)

\begin{tabular}{|l|l|l|l|}
\hline & \multicolumn{1}{|c|}{2018} & \multicolumn{1}{|c|}{2019} & \multicolumn{1}{c|}{2020} \\
\hline $\begin{array}{l}\text { Potential PIT debt or } \\
\text { overpayment, annually }\end{array}$ & Between 480 EUR debt and & Between 552 EUR debt and & $\begin{array}{l}\text { Between 600 EUR debt and } \\
\text { 600 EUR overpayment }\end{array}$ \\
\hline
\end{tabular}

After the submission of annual income report the overpayment of PIT may appear if:

1. The applied monthly non-taxable minimum is lower than the final annual indicator;

2. Historic earnings have been higher than actual;

3. Person's earnings are irregular and volatile or there has been some kind of distinct income.

Consequently, the debt arises, then:

1. The applied monthly non-taxable minimum is higher than the final annual indicator;

2. Historic earnings have been lower than actual;

3. Person's earnings are irregular and volatile, there has been some kind of distinct income or the person has just started or renewed the work experience, e.g. after unemployment, childraising vacation, etc.

Taking into consideration that historic earnings usually are not equal to present ones, the re-estimation of nontaxable minimum becomes available only after the submission of annual income report; thus since 201, all taxpayers should submit annual income report which justifies the amount of debt or overpayment and informs about it. 
The fact that a taxpayer doesn't know the size of non-taxable minimum complicates PIT implementation, therefore, the tax doesn't comply with the general principles of taxation, namely, simplicity.

According to the assessments of this stud, the highest level of debt may achieve 480 euro in 2018. It is obvious that the mentioned consequences haven't been envisaged in the framework of PIT reform. The emergence of debt risk due to the application of non-taxable minimum argues the efficiency and fairness of the PIT system. The mentioned consequences also conflict with the fundamentals of tax theory, i.e. “(...) tax system should provide the lowest amount of mandatory payments, thus minimizing the expenditures related to tax payments and tax administration" (Ketners, 2013); “(...) conscientious taxpayer should not be harmed by the gaps of tax system” (Ketners, 2013). Latvian PIT system at present provides the opposite.

The next aspect of PIT reform is an opportunity to apply the substantiated spending. The analysis shows that despite the provided rights not all taxpayers can realize this opportunity. The amount of taxable income that ensures an opportunity to deduct substantiated expenditures has risen in recent years. Despite the rights to apply mentioned spending, a significant number of taxpayers don't have such an opportunity; hence an "imaginary" benefit exists but it cannot be used. Table 5 illustrates the outlined trend.

Table 5. Annual gross income that doesn't provide an opportunity to deduct substantiated expenditures in 2015-2018, EUR (source: authors' estimation based on PIT legislation norms)

\begin{tabular}{|c|c|c|c|c|c|}
\hline & 2015 & 2016 & 2017 & 2018 & 2019 \\
\hline no dependants & up to 600 EUR & up to 1200 EUR & up to 1200 EUR & up to 3000 EUR & up to 3600 EUR \\
\hline 1 dependant & up to 3000 EUR & up to 3600 EUR & up to 4200 EUR & up to 5400 EUR & up to 6000 EUR \\
\hline 2 dependants & up to 5400 EUR & up to 6000 EUR & up to 6600 EUR & up to 7800 EUR & up to 8400 EUR \\
\hline 3 dependants & up to 7200 EUR & up to 7800 EUR & up to 8400 EUR & up to 9600 EUR & up to 10800 EUR \\
\hline 4 dependants & up to 9600 EUR & up to 10200 EUR & up to 10800 EUR & up to 11400 EUR & up to 13200 EUR \\
\hline 5 dependants & up to 12000 EUR & up to 13200 EUR & up to 13200 EUR & up to 13800 EUR & up to 15600 EUR \\
\hline 6 dependants & up to 13800 EUR & up to 15000 EUR & up to 15600 EUR & up to 16200 EUR & up to 19200 EUR \\
\hline
\end{tabular}

Table 6 demonstrates the assessment of the number of taxpayers without an opportunity to apply the substantiated expenditures. Significant growth of indicator may be observed in 2017-2019.

Table 6. Number of taxpayers without an opportunity to deduct substantiated expenditures in 2015-2018, persons (source: authors' estimation based on the unpublished data of SRS and SSIA)

\begin{tabular}{|c|c|c|c|c|c|}
\hline & 2015 & 2016 & 2017 & 2018 & 2019 \\
\hline no dependants & 62149 & 57194 & 57009 & 139851 & 160121 \\
\hline 1 dependant & 13809 & 14146 & 10776 & 22399 & 26534 \\
\hline 2 dependants & 12157 & 14249 & 10850 & 13765 & 16469 \\
\hline 3 dependants & 4725 & 3561 & 3180 & 3683 & 4773 \\
\hline 4 dependants & 1412 & 957 & 653 & 849 & 818 \\
\hline$>5$ dependants & 507 & 306 & 246 & 275 & 294 \\
\hline
\end{tabular}

If a person's income is enough for the application of the substantiated expenditures the annual income report must be submitted since the application is provided only on the basis of the annual report. Taking into consideration that monthly earning of $67.2 \%$ of taxpayers have been up to 1000 euro in 2018 and 1000 euro has been the maximum income that has provided rights to apply the projected non-taxable minimum, all $67.2 \%$ of taxpayers should submit the annual income report. Summarizing $67.2 \%$ and those with substantiated spending it is possible to conclude that almost all taxpayers should submit an annual income report. Thus, PIT reform undoubtedly increases the costs of PIT administration.

The legislation in force defines the objective of PIT reform as the provision of non-taxable minimum during the current year. This solution is especially significant for low-income earners. Despite the fact that especially low-income earners have been under the risk of tax debt due to the implementation of non-taxable minimum, it is necessary to admit that they have got wider support, but the way the support has been organized hasn't met the objectives of the reform. Refunding on the basis of annual income report doesn't ensure the opportunity to realize welfare rights promptly due to the following statements:

1. The essence of the non-taxable minimum is the provision of income minimum necessary for an individual's existence. It's refunding a year later it is not prompt and fair;

2. At least a year later refunding means that a taxpayer lends money and state borrows it without any interest payments disrupting the principle of tax neutrality and thus the principle of fairness;

3. In practice, the refunding may be carried out approximately in 18 months or even later - up to 3 years. Taking into account the absence of interest payments it is reasonable to claim that taxpayer's wealth declines because of inflation and lost investment alternatives. 
Table 7 illustrates the reduction rate. The discount rates have been set according to the average deposit rate ( $1 \%)$, inflation (3\%) and consumer loan's average interest rate $(6 \%)$ in Latvia.

Table 7. Refunding value reduction rates at different discount rates, \% (source: authors' estimation)

\begin{tabular}{|c|c|c|c|}
\hline Discount rate/Period & At 1\% & At 3\% & At 6\% \\
\hline 1 year & 1 & 2.9 & 5.7 \\
\hline 2 years & 2 & 5.7 & 11 \\
\hline 3 years & 2.9 & 8.5 & 16 \\
\hline
\end{tabular}

In the assessment of net earning, the authors have considered the changes regarding the modifications of PIT legislation adopted in 2018. If the taxpayers are not split into groups according to the amount of dependants estimation of effect in a broader sense shows that positive earnings' shift has been achieved (Table 8).

Table 8. Impact of PIT amendments in 2016-2018 (source: authors' estimation based on the unpublished data of SRS and SSIA)

\begin{tabular}{|c|c|c|c|c|c|}
\hline \multicolumn{2}{|c|}{} & \multicolumn{2}{|c|}{ Positive impact } & \multicolumn{2}{c|}{ Negative impact } \\
\hline Year & Number of taxpayers & $\begin{array}{c}\text { Number of } \\
\text { taxpayers }\end{array}$ & $\begin{array}{c}\text { \% of the whole } \\
\text { group }\end{array}$ & $\begin{array}{c}\text { Number of } \\
\text { taxpayers }\end{array}$ & \% of the whole group \\
\hline $2016 / 2015$ & 781006 & 557391 & $71.4 \%$ & 4523 & $0.6 \%$ \\
\hline $2017 / 2016$ & 780487 & 333207 & $42.7 \%$ & 265412 & $34.0 \%$ \\
\hline $2018 / 2017$ & 798890 & 677457 & $84.8 \%$ & 59320 & $7.4 \%$ \\
\hline
\end{tabular}

However, the assessment of specific groups demonstrates decreasing positive effect caused by the number of dependants, e.g. only $30.4 \%$ of taxpayers with 5 dependants has a positive impact on their earnings. Table 9 shows the specified results of the reform.

Table 9. Impact of PIT amendments on specific groups of taxpayers in 2016-2018

(source: authors' estimation based on the unpublished data of SRS and SSIA)

\begin{tabular}{|c|c|c|c|c|}
\hline & \multicolumn{2}{|c|}{ Positive impact } & \multicolumn{2}{c|}{ Negative impact } \\
\hline Taxpayer's profile & Number of taxpayers & $\%$ of the whole group & Number of taxpayers & $\%$ of the whole group \\
\hline All taxpayers & 677457 & $84.8 \%$ & 59320 & $7.4 \%$ \\
\hline no dependants & 520677 & $87.1 \%$ & 25993 & $4.3 \%$ \\
\hline 1 dependant & 107716 & $85.0 \%$ & 9685 & $7.6 \%$ \\
\hline 2 dependants & 41077 & $69.6 \%$ & 17644 & $29.9 \%$ \\
\hline 3 dependants & 7144 & $59.6 \%$ & 4808 & $40.1 \%$ \\
\hline 4 dependants & 748 & $43.5 \%$ & 973 & $56.5 \%$ \\
\hline 5 dependants & 95 & $30.4 \%$ & 217 & $69.6 \%$ \\
\hline
\end{tabular}

\section{Conclusions}

Assessing PIT modifications in the framework of tax reform it is reasonable to conclude, that the principles of equality, neutrality, stability, and simplicity have not been maintained. In comparison with previous periods of 2016-2017 the nature and implementation of the non-taxable minimum due to its differentiation have become more complex and nontransparent. The tax reform has affected the majority of taxpayers, but its economic gain in 2018 is a 5 euro increase in monthly net income in case of one dependant and 0-28 euro increase in net income when implementing the nontaxable minimum. In 2019 the projected monthly increase in net income may achieve 6 euro for every dependant and 0-6 euro since the non-taxable minimum is applied.

Taxpayers, whose annual income has been lower than 1200 euro, have not gained net income growth because of the increased rate of employee's social insurance contribution. Taxpayers with annual gross income of 1800-55 000 euro have received a different increase in net income, but an average amount has not been significant - approximately 10 euro monthly. Starting with gross income of 55000 euro net income has been decreasing in 2018, however in 2019 for gross income in the interval of 55 000-62 800 euro net income is going to grow; thus the reduction of net income in 2018 is going to be refunded by its increase in 2019. The stated objective of inequality reduction has not been obtained; in 2019the income tax rate for annual income higher than 55000 euro has been decreased, therefore net income is increasing in that case.

The authors assume that in case of Latvia better solution for inequality reduction might become rising including the minimum wage. If one of the main ideas of the reform is to provide prompt financial support via the implementation of deductions and non-taxable minimum, simultaneously ensuring the principles of solidarity and fairness, it would have been more reasonable to keep some fixed amount of non-taxable minimum for taxpayers with annual income 
lower than 20004 euro and not to implement any non-taxable minimum in case of notionally rich individuals (assuming that the PIT system stays unchanged and non-taxable minimum increase is more rapid). An opportunity to obtain some amount of non-taxable income promptly would have been provided, but its differentiated amount would have been received on the basis of annual income report. For maintaining the fairness and equality in labor tax system the authors suggest assessing all taxpayers equally by introducing the implementation of equal non- taxable minimum. Consequently, the risk of tax debt occurrence might be minimized. However, this proposal does not solve the main problem- an opportunity to implement the full amount of provided deductions and substantiated expenditures. The taxable income in Latvia is dramatically small.

Latvian government must ultimately finish the process of developing the standards of minimum income. That standard might provide the link to the amount of non-taxable minimum and its prompt and relevant updating. It is essential to estimate tax deduction, non-taxable minimum, social security benefit, and minimum wage systemically in the correlation with minimum income and poverty risk.

\section{Acknowledgements}

The authors appreciate the juridical guidance provided by the personnel of the Ombudsmen of the Republic of Latvia

\section{Funding}

This study has been conducted in the framework of Efficiency Cooperation Project "The Assessment of Implementation Problems Efficiency, and Solutions for Non-Taxable Minimum, Deductions and Substantiated Expenditures in the Context of Tax Reform in Latvia" financed by the University of Latvia and the Ombudsmen of the Republic of Latvia.

\section{Disclosure statement}

Authors do not have any competing financial, professional or personal interests from other parties.

\section{References}

Andrejeva, V., \& Ketners, K. (2007). Valsts ien̦ēmumu teorijas pamati, mācību grāmata. Rīga: RTU Izdevniecība.

Balodis, R. (2014). Latvijas Republikas Satversmes komentāri. Ievads. I nodaḷa. Vispārējie noteikumi.2014. Rīga: Latvijas Vēstnesis.

Bird, M., \& Zolt, E. (2005). The limited role of the personal income tax in developing countries. Journal of Asian Economics, $16(2005), 928-946$.

Bird, M., \& Zolt, E. (2005). The limited role of the personal income tax in developing countries. Journal of Asian Economics, 930.

Cabinet of Ministers. (2017a. gada 14. November). Ministru kabineta 2017. gada 14. novembra noteikumi Nr. 676 "Noteikumi par neapliekamā minimuma un nodokḷa atvieglojuma apmēru iedzìvotāju ienākuma nodokḷa aprēknināšanai” anotācija. Ielādēts 2018. gada 5. December no Cabinet of Ministers: http://tap.mk.gov.lv/lv/mk/tap/?pid=40438733

Cabinet of Ministers. (2017b, December 4). Noteikumi Nr.676 par neapliekamā minimuma un nodokla atvieglojuma apmēru iedzìvotāju ienākuma nodokl̦a aprēķināšanai. Retrieved January 25, 2018, from likumi.lv: https://likumi.lv/ta/id/295500noteikumi-par-neapliekama-minimuma-un-nodokla-atvieglojuma-apmeru-iedzivotaju-ienakuma-nodokla-aprekinasanai

Cabinet of Ministers. (2017c, May 24). Par Valsts nodokḷ u politikas pamatnostādnēm 2018.-2021. gadam. Retrieved November 20 , 2018, from likumi.lv: https://likumi.lv/doc.php?id=291013

Central Statistical Bureau of Latvia. (2018). Central Statistical Bureau of Latvia. Retrieved from www.csb.gov.lv

Constitutional Court of the Republic of Latvia. (2006). Sarersmes tiesas 2006.gada 11.decembra spriedums lietā Nr.2006-10-13 . Riga: Constitutional Court of the Republic of Latvia.

Constitutional Court of the Republic of Latvia. (2007). Satversmes tiesas 2008. gada 3. aprīla sprieduma lietā Nr. 2007-23-01 7. Riga: Constitutional Court of the Republic of Latvia.

Constitutional Court of the Republic of Latvia. (2010). Satversmes tiesas 2011. gada 20. maija sprieduma lietā Nr. 2010-70-01 . Riga: Constitutional Court of the Republic of Latvia.

Constitutional Court of the Republic of Latvia. (2017). Satversmes tiesas 2017. gada 19. oktobra spriedums lietā Nr. 2016-14-01 . Riga: Constitutional Court of the Republic of Latvia.

European Commission. (2014, December). Tax expenditures in direct taxation in EU Member States. Retrieved December 10, 2018, from European Commission: http://ec.europa.eu/economy_finance/publications/

European Commission. (2015). Taxation in the European Union- Towards Simple, Fair and Efficient Taxation in the European Union. Retrieved December 12, 2018, from European Commission: https://ec.europa.eu/taxation_customs/sites/taxation/ files/resources/documents/taxation/gen_info/tax_policy/taxation_internal_market_en.pdf 
Government of the Republic of Latvia. (2017, July 28). 2017.gada 28.jūlija likuma "Grozījumi likumā "Par iedzīvotāju ienākuma nodokli", anotāciju. Retrieved December 10, 2018, from Saeima:

http://titania.saeima.lv/LIVS12/saeimalivs12.nsf/0/FDE50450C2B3A295C225815A0054340B?OpenDocument

Govori, F. (2015. gada 30. March). A different approach of tax progressivity measurement. MPRA Paper No. 62846.

James, S., \& Nobes, C. (2010/2011). The economics of taxation: principles, policy and practice. Birmingham: Fiscal Publications.

Kakwani, N. (1977). Measurement of tax progressivity: An international comparison. The Economic Journal, 87, 71-80.

Ketners, K. (2013). Nodokḷi un nodevas Latvijā un Eiropā. Vispārīgie aspekti. Rīga: Info tilts.

Konstitucionālo tiesību komisija. (2012). Par Latvijas valsts konstitucionālajiem pamatiem un neaizskaramo Satversmes kodoli. Latvijas Vēstnesis, p. 109.

Koval̦evska, A. (2011). Cilvēka pamattiesības. In R. Balodis, Latvijas Republikas Satversmes komentāri, VIII nodal̦a. Cilvēka pamattiesības (p. 562). Riga: Latvijas Vēstnesis.

Musgrave, R. A., \& Thin, T. (1948). Income tax progression. The Journal of Political Economy, 56(6), 498-514.

Pētersons, M. ,. (2001, May 03). Vispārējie tiesību principi un Satversmes tiesas kompetence. Jurista Vārds(18), 16.

Pigou, A. (1960). A study in public finance (3rd Revised ed.). London, New York: Macmillan,St Martin's Press.

Satversmes tiesa. (2016, January 14). Sarversmes Tiesa. Retrieved December 2, 2018, from Satversmes tiesas tiesneses D.Rezevskas atsevišḳo domu 2017.gada 2.novembra lietā Nr.2016-14-01 3.punkts:

http://www.satv.tiesa.gov.lv/web/viewer.html?file=http://www.satv.tiesa.gov.lv/wp-content/uploads/2016/07/2016-14-

01_atseviskas_domas_Rezevska-1.pdf\#

Slemrod, J. (1996). Tax progressivity and income inequality. Cambridge, UK: Cambridge University Press.

State Revenue Service. (2019). Retrieved February 15, 2019, from www.vid.gov.lv

Suits, D. B. (1977). Measurement of tax progressivity. American Economic Review, 67(4), 747-752.

Šulmane, D. (2013). Konstitucionālas tiesībpolitikas semināra materiāl. Tiesību normu efektivitātes problemātika un aktualitāte XX un XXI gadsimta tiesību sociologijā. Bīrinii.

The Parliament of the Republic of Latvia. (1922, February 15). Constitution of the Republic of Latvia. Retrieved November 21, 2018, from likumi.lv: https://likumi.lv/doc.php?id=57980 